\title{
Infections by Helminth Parasites in "Puyenes", Galaxias maculatus (Galaxiidae, Salmoniformes), from Southern Argentina with Special Reference to Tylodelphys barilochensis (Digenea, Platyhelminthes)
}

\author{
J Revenga ${ }^{+}$, P Scheinert
}

Laboratorio de Ictiopatología, Centro Regional Universitario Bariloche, Universidad Nacional del Comahue, 8400 Bariloche, Argentina

The occurrence of Tylodelphys barilochensis, Acanthostomoides apophalliformis, Contracaecum sp. and Camallanus corderoi infecting Galaxias maculatus ("puyenes") was quantified for the first time in Lake Nahuel Huapi, southern Argentina. T. barilochensis was recorded in this lake for the first time. The role of $\mathrm{G}$. maculatus population in transmission of parasites to the salmonids is more important for Contracaecum sp. (prevalence 14-34\%) and A. apophalliformis (prevalence 30-54\%) than for $\mathrm{C}$. corderoi (prevalence 6-8\%). The absence of Diphyllobothrium spp. in samples shows that the G. maculatus population does not play any role in the life cycles of these important zoonotic parasites. The sex of the host had no effect on T. barilochensis abundance. Statistical differences in T. barilochensis abundance between "puyenes" of the same size class between sampling stations and positive correlation between prevalence of infected snails and $\mathrm{T}$. barilochensis abundance in fish suggest that different stocks have been sampled. Factors influencing T. barilochensis abundance are discussed.

Key words: parasitism - Tylodelphys - Galaxias maculatus - salmonids - southern Argentina

Salmonid fishing is of economic importance in the Argentinian Patagonia.

The "puyen" Galaxias maculatus (Galaxiidae, Salmoniformes) is a small autochthonous fish (total asymptotic growth length $=97 \mathrm{~mm}$ in Ezquerra pond, near Lake Nahuel Huapi), (Cervellini et al. 1993) that inhabits southern South America and Oceania (Quaggiotto \& Valverde 1993) and may be predated by salmonids whereby transmission of parasites may occurr (Revenga 1993). Studies in New Zealand (McDowall 1968) and Australia (Pollard 1971) agree that most of each population dies during its first year, immediately after spawning, but a small proportion might reach three years of age.

In a population study in a dam in North Patagonia, Ferriz (1987) observed an annual cycle. The "puyenes" are found in Patagonia in various lakes and rivers where they inhabits littoral waters.

\footnotetext{
This project was partially supported by grant No. B029 from Universidad Nacional del Comahue.

${ }^{+}$Corresponding author. Present address: Depto. de Acuicultura, CRUB, Universidad Nacional del Comahue, Quintral 1250, 8400 Bariloche, Argentina. Fax: +54-94422111. E-mail: jrevenga@bariloche.com.ar Received 26 August 1998

Accepted 19 May 1999
}

Different helminth parasites have been recorded in "puyenes" from the Nahuel Huapi Lake (Ortubay et al. 1994) and information on their biology appears in articles by Szidat and Nani (1951), Szidat (1956), and Torres et al. (1990).

Tylodelphys is a digenetic trematode genus and its species range extensively in both the northern and southern hemispheres. The species paraziting "puyenes" that have been described for the region are T. argentinus, T. barilochensis and T. crubensis (Quaggiotto \& Valverde 1992). Adults develop in the intestine of ichthyophagous birds (species unknown for the region). The first stage (miracidium) is a swimming larva. The following stages (sporocysts, rediae, cercariae) develop in snails (Chilina sp.).When the cercariae emerge, they can swim and actively infect "puyenes", where the metacercariae develop (Scheinert et al. 1997).

This paper presents the first quantitative parasitological records of "puyenes" from Nahuel Huapi Lake and analyses species abundance of $T$. barilochensis and migratory movements of fishes.

\section{MATERIALS AND METHODS}

The study was carried out in Lake Nahuel Huapi, in the Nahuel Huapi National Park and Reserve $\left(40^{\circ} 8^{\prime}-41^{\circ} 35^{\prime} \mathrm{S}, 71^{\circ} 2^{\prime}-71^{\circ} 57^{\prime} \mathrm{W}\right)$. The coastline is very irregular with a series of bays, peninsulas, and isthmuses, gravel or sandy beaches, and rocky cliffs, favouring the existence of differ- 
ent microhabitats. The lake bed harbors few macrophytes, partly because of the low proportion of shallow waters and partly because of wave action, strongly influenced by west winds (Thomasson 1959). The town of San Carlos de Bariloche is located on the eastern coast.

Six sampling stations were established on the eastern littoral zone over aproximately $40 \mathrm{~km}$ (named A, B, C, D, E and F). Distance from the town of San Carlos de Bariloche increases from A $(0 \mathrm{~km})$ to $\mathrm{F}(40 \mathrm{~km})$. From January 20 to February 10, 1994, 579 "puyenes" G. maculatus, were trapped (Table I). Traps were submerged at a depth not greater than $0.5 \mathrm{~m}$ for 1-5 days. After not longer than five days, fish were put to death, total length and weight were measured and sex was determined (162 males and 154 females; the remaining fish were inmature). Necropsies were carried out under stereomicroscope and internal helminth parasites collected, identified and counted.

On February 12 and 13, 1994, Chilina dombeiana snails were sampled from the Nahuel Huapi stations where fish were captured. Random samples were taken (manual collection within an area of 1 $\mathrm{m}^{2}$ ) every $4 \mathrm{~m}$ along a transect of approximately $150 \mathrm{~m}$, at a depth between 0.0 and $0.40 \mathrm{~m}$. From each sample, 70 snails were separated at random in individual glasses at room temperature, to observe cercariae emergence. The cercariae that emerged were "furcocercaria type A" and "echinocercaria sp.", as described by Ostrowsky and Quaggiotto (1995), but never coexisted. Absence of trematode larvae was verified by necropsy under stereomicroscope for snails that failed to shed cercariae. Specific identity of cercariae was determined by experimental infections with "furcocercaria type A" on "puyenes" free of parasites, as in Scheinert et al. (1997). They were found to correspond to T. barilochensis (Quaggiotto \& Valverde 1992).

In this paper, the terms abundance and prevalence are used according to the recommendations of Margolis et al. (1982).

The Mann-Whitney, Kruskall-Wallis and multiple comparison (Conover 1980) tests were used to compare abundances. Correlation analysis was used to relate prevalence of infected snails and parasite abundance in fish and density of snails and parasite abundance in fish. The significance level considered was 0.05 .

\section{RESULTS}

Table I shows the number of "puyenes" of different size classes captured at the different sampling stations.

The following parasites were found: $T$. barilochensis (unencysted metacercariae in the encephalic cavity), A. apophalliformis (metacercariae encysted in the liver), Contracaecum sp. (larvae in the body cavity) and C. corderoi (adults in intestine). Table II shows abundance and prevalence of the parasites found at the different sampling stations.

For T. barilochensis, no significant difference in parasite abundance was found between fish sexes. The analysis of $T$. barilochensis metacercariae abundance for each "puyenes" size class showed significant differences between sites for size classes 41-50, 51-60 and > $60 \mathrm{~mm}$ (KruskallWallis test). Comparing abundance in pairs ( $a$ posteriori), the multiple comparison test permits a distinction of fish as follows (Fig. 1), in size class 41-50 mm 3 stocks (A, B-E, C-D). In size class 51-60 mm 3 stocks (B-E, C, F) and in size class > $60 \mathrm{~mm} 3$ stocks (B, E, F). Increased abundance with fish size and stocks of fish is also shown (Fig. 1). Fig. 2 shows positive correlation between prevalence of snails infected by $T$. barilochensis and parasite abundance in fish of 3 size classes (41-50, $51-60,>60 \mathrm{~mm}), \mathrm{r}^{2}=0.98, \mathrm{r}^{2}=0.96$ and $\mathrm{r}^{2}=0.79$ respectively. In contrast, Fig. 3 shows no correlation between density of snails and abundance of parasites in fish of size classes 41-50, 51-60 and > $60 \mathrm{~mm} ; \mathrm{r}^{2}=0.44, \mathrm{r}^{2}=0.40$ and $\mathrm{r}^{2}=0.41$.

\section{DISCUSSION}

This is the first time that the presence of $T$. barilochensis, A. apophalliformis, Contracaecum sp. and C. corderoi in G. maculatus is quantified in the Nahuel Huapi National Park and Reserve. It

TABLE I

Number of Galaxias maculatus per size class captured in different sampling stations of Lake Nahuel Huapi

\begin{tabular}{lrrrrrrr}
\hline & \multicolumn{7}{c}{ Sampling station } \\
\cline { 2 - 7 } Size $(\mathrm{mm})$ & A & B & C & D & E & F & Total \\
\hline $31-40$ & 6 & 25 & 25 & 0 & 28 & 0 & 84 \\
$41-50$ & 71 & 27 & 51 & 32 & 31 & 8 & 220 \\
$51-60$ & 4 & 51 & 33 & 8 & 34 & 30 & 160 \\
$>60$ & 0 & 36 & 2 & 5 & 32 & 40 & 115 \\
\hline Total & 81 & 139 & 111 & 45 & 125 & 78 & 579 \\
\hline
\end{tabular}



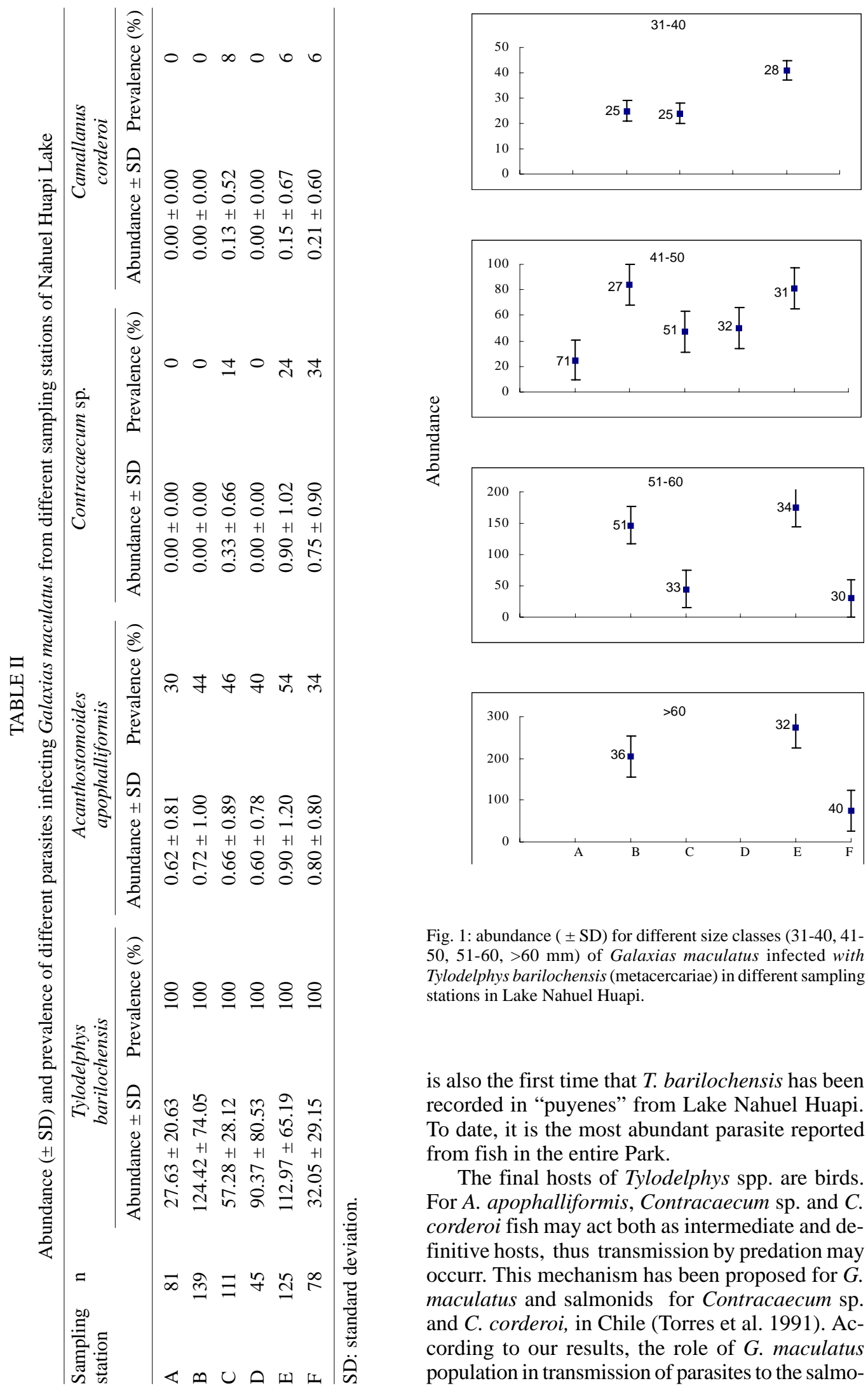

Fig. 1: abundance $( \pm \mathrm{SD})$ for different size classes (31-40, 41 $50,51-60,>60 \mathrm{~mm})$ of Galaxias maculatus infected with Tylodelphys barilochensis (metacercariae) in different sampling stations in Lake Nahuel Huapi.

is also the first time that $T$. barilochensis has been recorded in "puyenes" from Lake Nahuel Huapi. To date, it is the most abundant parasite reported from fish in the entire Park.

The final hosts of Tylodelphys spp. are birds. For A. apophalliformis, Contracaecum sp. and $C$. corderoi fish may act both as intermediate and definitive hosts, thus transmission by predation may occurr. This mechanism has been proposed for $G$. maculatus and salmonids for Contracaecum sp. and C. corderoi, in Chile (Torres et al. 1991). According to our results, the role of G. maculatus population in transmission of parasites to the salmo- 

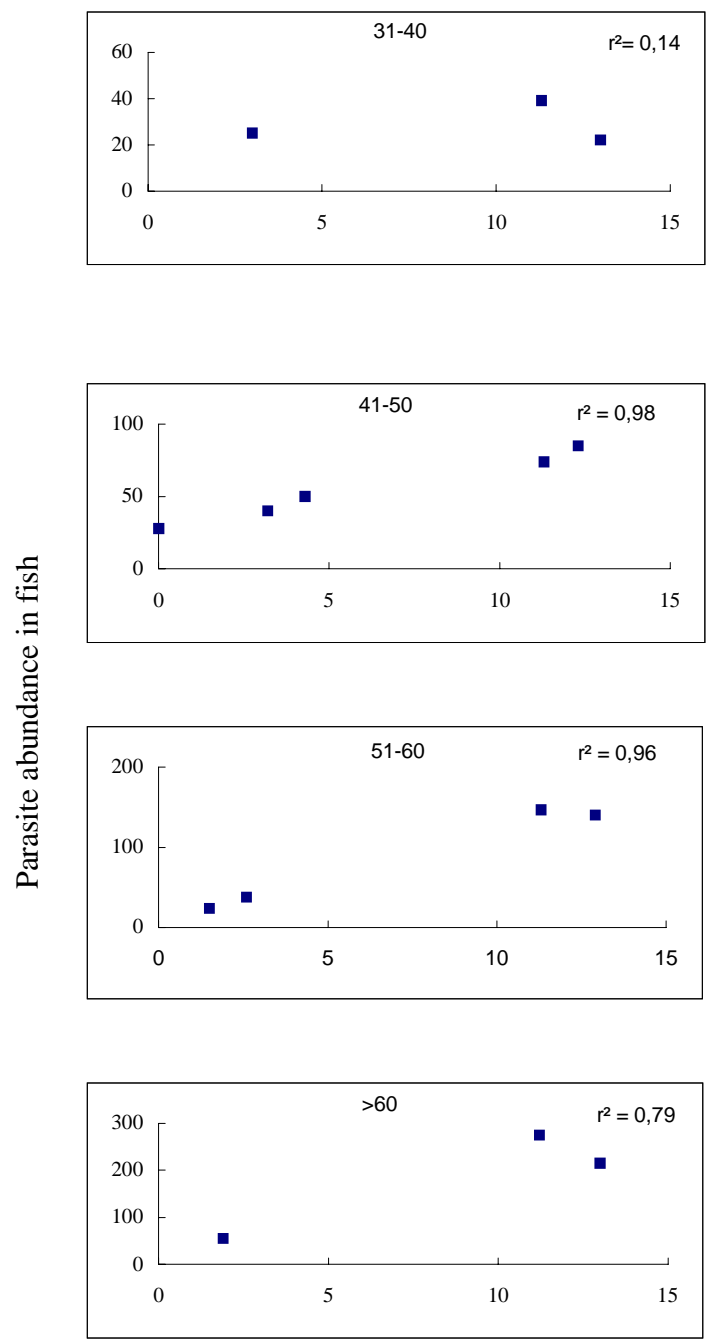

Fig. 2: correlation between prevalence of infected Chilina dombeiana and abundance of Tylodelphys barilochensis infecting Galaxias maculatus of different size classes (each point represents one sampling station).

nids is more important for Contracaecum sp. (prevalence 14-34\%) and A. apophalliformis (prevalence 30-54\%) than for $C$. corderoi (prevalence 6-8\%). Revenga (1993) reports two parasites with zoonotic importance: Diphyllobothrium dendriticum and D. latum in fish from Lake Moreno, which is connected with Nahuel Huapi Lake. He suggests that salmonids can act as paratenic hosts for both species and states the importance of studying the role of G. maculatus populations in the life cycle of $D$. dendriticum and $D$. latum. The absence of Diphyllobothrium spp. in this study shows that the G. maculatus population does not play a role in life cycles of these para-
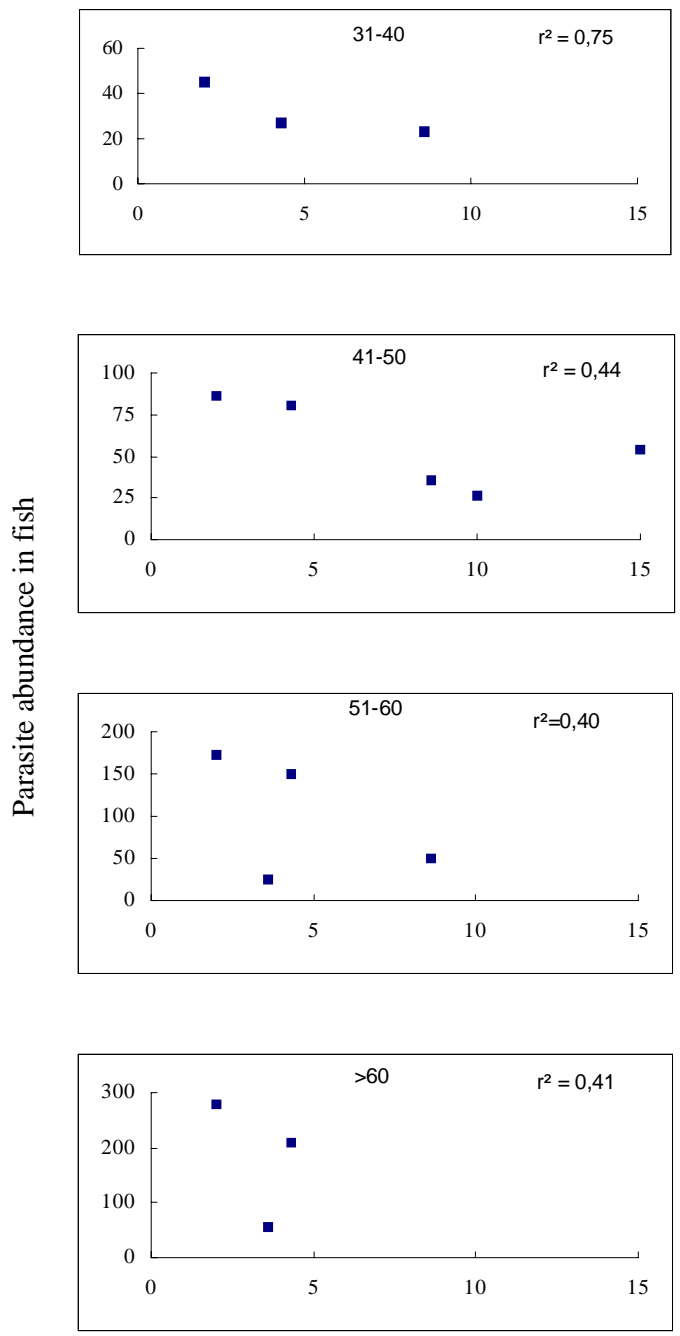

Fig. 3: the lack of correlation between density of Chilina dombeiana and abundance of Tylodelphys barilochensis infecting Galaxias maculatus of different size classes (each point represents one sampling station).

sites and contradicts the argument of salmonids as paratenic hosts.

The absence of significant differences in. $T$. barilochensis abundance between sexes shows that susceptibility to infection is not associated with sex.

The use of parasites for separating fish stocks has been reviewed by different authors (MacKenzie 1983, 1987, Lester 1990). In this study the absence of Contracaecum sp. and C. corderoi at stations A, B and D suggests different fish stocks. The significant differences in the abundance of $T$. barilochensis from fish in the same size (as age indicator) class from neighbouring stations (Fig. 1) reinforces the hypothesis of different stocks. 
When more than one size class repeats the same result (Fig.1) this idea is further reinforced. The positive correlation between metacercariae abundance and prevalence of infected snails (also analyzed by size class in "puyenes") at different stations (Fig. 2), constitutes additional information in favor of this hypothesis. All these results strongly suggest that different stocks have been sampled, although this does not exclude the possibility of a certain degree of mixing, which is difficult to quantify (Lester 1990).

This stock separation in small fishes with short lives (Gambusia affinis) was observed by Aho et al. (1982) and Camp et al. (1982) in studies on population biology of metacercariae of the family Diplostomatidae. The Lake Nahuel Huapi receives urban contaminants at some points. If the movement of fishes from place to place were restricted and certain stocks remained permanently in contaminated areas, the effect of contamination on fishes could be studied. Further studies including more sampling stations, greater sample size and analyses of water quality would be of interest.

The lack of correlation between density of snails and $T$. barilochensis metacercariae abundance in fishes analyzed by size class suggests that it is prevalence rather than number of previous hosts, that regulates parasite abundance in fishes. Thus, the controlling factor would be number of birds (definitive hosts) that visit or remain in different areas of the lake. Further studies are needed.

\section{ACKNOWLEDGMENTS}

To Eduardo Revenga for help with data processing and Clive R Kennedy for helpful criticism on a previous version of this paper.

\section{REFERENCES}

Aho JM, Camp JW, Esch GW 1982. Long-term studies on the population biology of Diplostomulum scheuring $i$ in a thermally altered reservoir. $J$ Parasitol 68: 695-708.

Camp JW, Aho JM, Esch GW 1982. A long-term study on various aspects of the population biology of Ornithodiplostomum ptychocheilus in a South Carolina cooling reservoir. J Parasitol 68: 709-718.

Cervellini PM, Battini MA, Cussac VE 1993. Ontogenetic shifts in the diet of Galaxias maculatus (Galaxiidae) and Odontesthes microlepidotus (Atherinidae). Environm Biol Fishes 36: 283-290.

Conover WJ 1980. Practical Nonparametric Statistics. 2nd ed., John Wiley and Sons Publishers, New York, 493 pp.

Ferriz RA 1987. Biología del puyen Galaxias maculatus (Jenyns) (Teleostomi, Galaxiidae) en un embalse norpatagónico. Ciclo de vida, ciclo gonadal y fecundidad. Rev Mus Arg B Riv Hidrobiol 5: 29-38.

Lester RJG 1990. Reappraisal of the use of parasites for fish stock identification. Aus J Mar Fresh Res 41:
855-864.

MacKenzie K 1983. Parasites as biological tags in fish population studies. Adv Appl Biol 7: 251-331.

MacKenzie K 1987. Parasites as indicators of host populations. Int J Parasitol 17: 345-352.

Margolis L, Esch GW, Holmes JC, Kuris AM, Schad GA 1982. The use of ecological terms in parasitology. J Parasitol 68: 131-133.

McDowall RM 1968. Galaxias maculatus (Jenyns), the New Zealand whitebait. Fish Res Bull (New series) 2: 1-84.

Ortubay SG, Semenas LG, Ubeda CA, Quaggiotto AE, Viozzi GP 1994. Catálogo de Peces Dulceacuícolas de la Patagonia Argentina y sus Parásitos Metazoos, Dir Pes Sub Rec Nat Prov R Negro Publishers, Bariloche, $110 \mathrm{pp}$.

Ostrowsky de Nuñez M, Quaggiotto A 1995. Trematodes larvales (Digenea) de las familias Diplostomidae, Strigeidae y Echinostomatidae en la Region Patagonica Argentina. Bol Chil Parasitol 50: 28-33.

Pollard DA 1971. The biology of a landlocked form of the normally catadromous salmoniform fish Galaxias maculatus (Jenyns). I. Life cycle and origin. Aus $J$ Mar Fresh Res 22: 91-123.

Quaggiotto EA, Valverde F 1993. Nuevas metacercarias del género Tylodelphys (Trematoda, Diplostomatidae) en poblaciones lacustres de Galaxias maculatus (Teleostei, Galaxiidae). Bol Chil Parasitol 47: 19-24.

Revenga J 1993. Dyphyllobothrium dendriticum and Dyphyllobothrium latum in fishes from southern Argentina: association, abundance, distribution, pathological effects, and risk of human infection. $J$ Parasitol 79: 379-383.

Scheinert P, Revenga J, Noguera P 1997. La migración de Tylodelphys barilochensis (Quaggiotto y Valverde, 1992) en Galaxias maculatus (Jenyns, 1842) y sus efectos sobre el hospedador. Rev Ictiol 5: 49-55.

Szidat L 1956. Über die parasitenfauna von Percichthys trucha (Cuv.and Val.) Girard der patagonischen gewässer und die beziehungen des wirtsfisches und seiner parasiten zur paläarktischen region. Arch Hydrobiol 51: 542-577.

Szidat L, Nani A 1951. Diplostomiasis cerebralis del pejerrey. Una grave epizootia que afecta a la economía nacional producida por larvas de trematodes que destruyen el cerebro de los pejerreyes. Rev Inst Nac Inv C Nat B Riv 1: 323-384.

Thomasson K 1959. Nahuel Huapi. Plankton of some lakes in an Argentine national park, with notes on the terrestrial vegetation. Ac Phyto Suec 42: 83.

Torres P, Teuber S, Miranda JC 1990. Parasitismo en ecosistemas de agua dulce de Chile. 2. Nematodos parásitos de Percichthys trucha (Pisces: Serranidae) con la descripción de una nueva especie de Camallanus (Nematoda: Spiruroidea). Stud Neotrop F Environm 25: 111-119.

Torres P, Cabezas X, Arenas J, Miranda JC, Jara C, Gallardo C 1991. Ecological aspects of nematode parasites of introduced salmonids from Valdivia River Basin, Chile. Mem Inst Oswaldo Cruz 86: 115122. 
